\title{
Local Wisdom from the Socio-Ecological Perspectives: Managing Former Mine Lands in Achieving Green Era
}

\author{
Wahyudi Himawan ${ }^{1}$, Fachrurrozie Sjarkowie ${ }^{2}$, Alfitri ${ }^{3}$ \\ 1,2\&3 (University of Sriwijaya, Palembang, INDONESIA)
}

\begin{abstract}
Indigenous Knowledge (IK) is a knowledge that originates from life and existing cultural values in an area. Indigenous Knowledge System (IKS) constructed from IK is believed to contain a variety of local knowledge that can be tested as local wisdom which is able to solve various environmental problems. It is indeed high time that a study is being conducted on various matters related to human life in developing the environment in order to examine the extent to which local wisdom has been applied at all stages of planning and developmental design. The natural environment is sometimes regarded as the cause of problems in human life, but still there is potential to address environmental problems. This study is very important to understand the ways how the various heritage, culture and local knowledge, especially the ones found in the management of former mind lands, by the community in order to create harmony between man and his environment. The aim of this study is to identify the types of local knowledge in the form of local wisdom available in the management of former mine lands. Local Wisdom studied is Indigenous Knowledge Systems (IKS) that can be the basis for initiating a Local Service System (LSS). Local knowledge examined in this study is obtained from the expression of paradigm and patterns of action manifested by communities living adjacent to the former mine lands. The findings of this study can be used to apply the concept of sustainable development towards the green era and become guidelines for people in the areas that have the characteristics of former mine lands and identical or nearly identical culture.
\end{abstract}

Keywords: local knowledge, former mine lands, continuous development, green era

\section{Introduction}

The beaches in Bangka and Belitung islands are filled with stunningly attractive giant-sized overlaying granite stones which make the appearance of the landscape looks unique as opposed to beaches in Indonesia. If we traverse across Bangka islands by plane, we can clearly see an aerial view of the scenic gaping holes of former tin mine lands that are hundreds years old. These views have not changed much until now as these areas are damaged by rampant illegal mining, also known by the public as Non-conventional Mining Activities (Tambang tidak Konvensional - TI), while these lakes also discharge dirty water containing chemicals which can cause ill-health. For example, consider Rangkui River which runs through the city Pangkalpinang. This river was used for bathing and drinking, and there were a lot of fish that might be caught. However, the expansion of Non-conventional Mining Activities in upstream of Rangkui River has caused the water that was once clean and clear to become dirty, containing sludge that comes from the water used for tin mining.

The idea that former mine lands do not have the potential to be repaired as before has been immersed in the minds of the people as well as entrepreneurs who conduct tin mining. They feel that an extended time and advanced technology as well as enormous cost are needed to restore the lands. In this case, the community's local knowledge is ignored and not considered in the management of the mine lands.

It seems that lessons should be learned from the people of Phuket Island in Thailand. In comparison with the island of Bangka, Phuket was also a tin mine which has been shut down for about sixteen years. However, the people of Phuket seek their fortune in tourism industry. The key issue emerges from this explanation is that: In what way can the local wisdom of the people around the tin mines can be synchronized based on the knowledge of local communities in developing a policy for managing former mine lands in order to increase the welfare of people around those lands. The questions are: (1) How local wisdom can be utilized as the socio-ecological values among people living around the former mine lands; (2) How Indigenous Knowledge Systems (IKS) or local community knowledge systems can be basic principles in managing natural surroundings around the former mine lands; (3) How to develop basic strategies for the maintenance of the former mine areas based on local wisdom towards achieving green era.

\section{Ecological Developmet}

The effects of development, poverty and damages done onto the environment are most often interrelated so that one problem hardly ever occurs alone. The effects may happen in succession or recurring. Thus, an overview of the ecological relationship between the three is a causal-effect relationship. Development 
is planned social change and should be a priority for the government in improving social welfare and reduce poverty. In socio-ecological perspective, poverty is a situation faced by people who have less access to management of natural resources. In practice, many development programs are conducted by the government with the purpose of earning money and ignoring the environmental aspects (MIPI, December 2013). For example, the government has granted permission for mining, awarded business license, and permitted tenure on employers, and warranted the management of other natural resources, which all can be considered as allowing activities that may contribute to environmental degradation.

The entrepreneurs activities, be it conducted at a smaller or larger scale, which are not responsible for the management of former mining land (reclamation, recovery, restoration) may be the main cause of the damage done onto natural surroundings. Non-conventional mining activities done by the public, although not as rigorous as the entrepreneurs, also contribute to the damage of natural surroundings. Because of poverty, people are forced to do all sorts of things in order to survive although sometimes the actions may threaten their lives, for example, the non-conventional tin mining activities had claimed the lives of several workers. This study believes and proposes that a balanced relationship between social and ecological aspects in the concept of ecological modernization towards a green era, which is based on community participation by popularity of local wisdom as Indigenous Knowledge System (IKS) is able to maintain and even enhance economic growth and improve social welfare. The concept of ecological modernization and development of a balanced ecosystem ecologically and socially is a gradual process. The balance intended is a social and ecological balance. Social and ecological imbalance occurs in the use of natural resources as perspective of positivism exists which considers saint as universal and the truest. However, apart from the saint world, there is a system called local knowledge (Indigenous Knowledge System) which is highly empirical and able to keep that balance.

Green social theory with the concept of sustainable development seeks to give attention to overcome the separation between humans and nature. Sustainable development is often synonymous with ecological modernization, as set out in the first seminar in WCED (World Commission on Environmental, Growth and Development, 1997). In this study, the term ecological modernization or socio-ecology are used to mean ecological development which maintains a balance between social systems and ecological systems that is enjoyed by the present and future generations. The assumption of socioecological growth is that socio-economic growth is reconciled with ecological sustainability.

Tin mining process is a complex process, which is characterized by not only ecological damage but also by conflicts over access to the resources and the trade - off needs among various stakeholders at various scales and strata (social status). A technical approach towards environmental assessment and rehabilitation of former tin mine lands that relies on merely technology alone will gradually and apparently lost its legitimacy and attention from the community. The attention of the community is now shifting towards a more participatory approach for integrated socioecological system. A socioecological and integrated participatory approach, based on local wisdom will take a variety of local sources of knowledge that accurately describes the complex process of socioecological system. Whitfield et al. (2011) stated that a successful management of damage done onto natural resources and the environment requires a strategy that can accommodate all or some of the interest of the stakeholders in the present and in the future. Past empirical study indicated that industrialization of such places have positively affected the quality of life among rural communities (Jalaluddin Abdul Malek et al. 2014).

\section{Objectives}

The study aimed at exploring how local wisdom can be utilized as the socio-ecological values among people living around the former mine lands. It also aimed at validating a model to integrate Indigenous Knowledge Systems (IKS) or local community knowledge systems in order to manage natural surroundings around the former mine lands. In addition the current study develops a model of strategies for the maintenance of the former mine areas based on local wisdom in order to achieve green era.

\section{Bangka Botanical Garden (BBG)}

\section{Findings And Discussion}

Johan, a native of Bangka, felt upset about the damaged environmental conditions and the way of thinking among the people in his society who always considered that former mined lands were no longer useful. However, he recalled his experience when visiting Phuket, Thailand. He was determined to transform the mined land around the beach resort of Pasir Padi in Pangkalpinang in order to be a region that has economic value, ecological and social. With great intentions to make the transformation, Johan then sought referral in Malaysia, Singapore and Thailand about the low-cost and efficient ways to improve the surrounding environment and get great benefits. The value of local knowledge that is portrayed by Johan is "It is usual to turn gold into gold, but it is incredible to turn garbage into gold." This is a real Indigenous Knowledge which exists among the members of the communities living in the mined land. However, because of lack of motivation and courage, the value of local wisdom was not raised. And Johan became the man who dared to express this local value. 
Johan started his long journey in 2005 by being an entrepreneur in tin smelter. When he first started, he had to face accusations saying that his smelter produced toxic and hazardous waste. He was passionate to provide evidences that the accusations were not true, so he made a pool at the back of his smelter and filled the pool with the waste from his smelter, and then filled the pool water with tilapia fish, He proved the accusations wrong as apparently the fishes were alive and healthy. As he was still curious, Johan planted chili and tomato trees and watered those plants with the waste water from his smelter. He found that the chili and tomato plants were apparently growing well and fertile especially when they were nurtured well.

Johan still did not feel quite satisfied with these small successes so he undertook to cultivate more plants in a wider area around the mine. The plants were jambu mete, sengon, ketapang, and pucuk merah at the area where there used to be mining activities which were by the beaches. However, the people in the surrounding community did not fully supported him, and they even caused damages to the cultivated area by resuming their activities in mining as tin prices began to rise again and that land mines still contained traces of tin deposits. It is apparent that tin mining in Bangka Island is unique. When the tin price increases, everyone rushes to cultivate their tin mine. While when the tin price plummets, they leave their tin mines because they assume that it is a loss and difficult to obtain a return of their capital. When Johan and his team planted vegetations at the former mine land, they were confronted by the people in the community with machetes and wood because the people thought that Johan and his team intended to rob the land. He and his team were determined to start developing and pioneering a specific area to restore and repair the land at the former tin mine. According to Johan, the people of Bangka are characterized by a culture that can be summarized as DKN (Dak Kawa Nyusah), which means 'Do not want to try hard', and thus, firstly they need to be given a concrete example of best practices and shown evidence of success so that they would be persuaded to emulate a new activity. This area is called BBG (Bangka Botanical Garden), a park with the concept of eco-industry.

Johan's early startup capital when he began to develop BBG was 3 cows from Bali, 6 dairy cows (FH adult cows, and 14 calves. Cow manure is processed into compost fertilizer to neutralize water in the fish pond which is going to be built. Compost also restores nutrients in the soil which is necessary for the plants. Previously, the content of nutrients in the soil in the area is quite low because it was dominated by the former mine land which contains high vitamin $\mathrm{C}$, while the content of organic materials is very low which is only $2 \%$, making the soil not productive. Synergies between cattle, farms, and activities to improve the environment are supported by the local government and central government, as well as Department of Artificial Insemination (Dewan Inseminasi Buatan - BIB) of Lembang, Department of Fish Seed (Balai Benih Ikan) of Jawa Barat, and a few others. As a result, cow manure is processed into biogas and fertilizer, both compost and liquid. Water used for cleaning up contains micro-plankton which is used to feed the fish. Elephant grass is planted and fertilized using cow manure as fertilizer and it is harnessed to feed the cattle. This is a concept of ecological metabolism.

The green area is now $100 \mathrm{Ha}$, while the target is $150 \mathrm{Ha}$. The area of $300 \mathrm{Ha}$ owned from purchases made and some granted by the government of Pangkalpinang, are former mine lands. BBG now owns 400 cattle, both dairy and beef cows, which produces 45 ton per month, and the production of liquid fertilizer from fermented cow manure now reaches 500 liters per day; from 80 dairy cattle, BBG produces 160 liters of milk per day. Apart from that, BBG has donated 700 glasses of fresh milk to a number of schools in Bangka twice a year. The BBG agricultural activity has focused on planting dragon fruits, and is capable of producing $90 \mathrm{~kg}$ every time the fruits are harvested from a 1.6 ha area of land. Various decorative plants and native forest plants such as Bangka are also grown. In addition, BBG is also able to cultivate date palm plants in the 1.8 ha of area, as well as special plants from Bangka such as orchids and pelawan plants which are now almost extinct.

Johan's mission is to develop BBG into an area of research, sports education, tourism, and the most important thing is to be a role model to motivate the people around the former mine land to improve their environment, in order to achieve advancement of ecology, economy and societal perception towards former mine lands which can change to be more fruitful such as turning a sewage into a blessing. At the time of this study is being reported, BBG has always been visited by students who range from kindergarten to secondary school. Johan was at the time pioneering a training institution which offers environmentally greening program, empowering the use of environment for students at all levels between kindergarten and secondary. Johan hopes that the next generation would love and care for the environment since they are still young.

According to Johan, BBG promises more fortune and benefits from both aspects of economy, ecology and social compared to smelter enterprise. This is because a continuous socioecological activity is very much needed by the society in order to materialize the aim for sustainable development among generations. In contrast, smelter enterprise only benefits entrepreneurs who incidentally come from overseas to invest and at the same time sucking up the native's environmental products, leaving the natives of the land being poor and needy in their own land. 


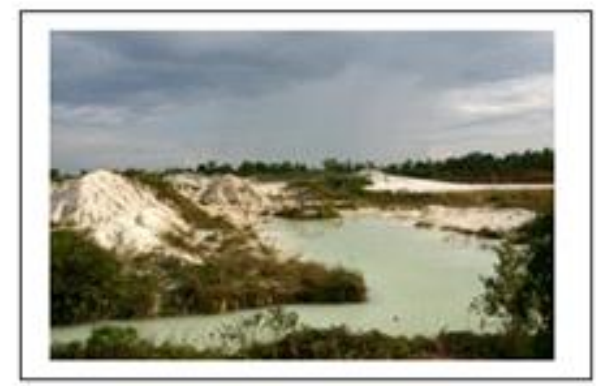

BBG - nine years ago (2005)

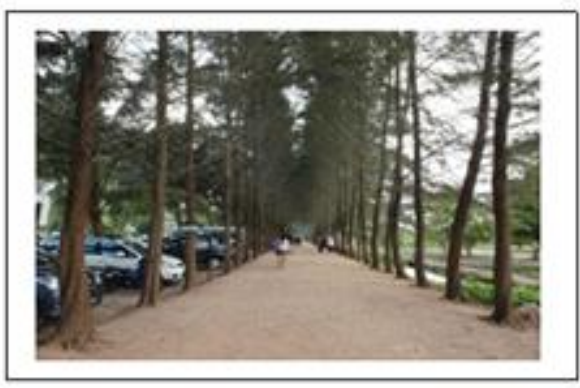

BBG - now (2014)

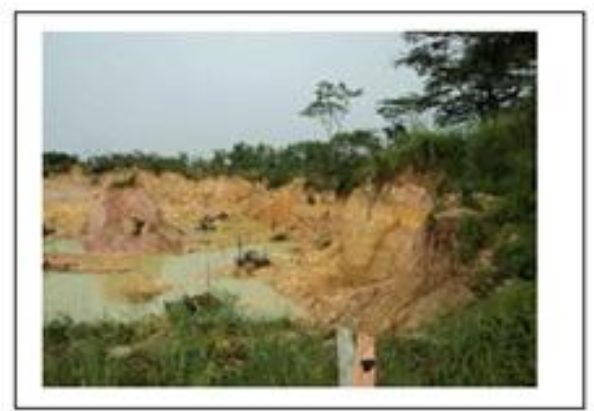

BBG - nine years ago (2005)

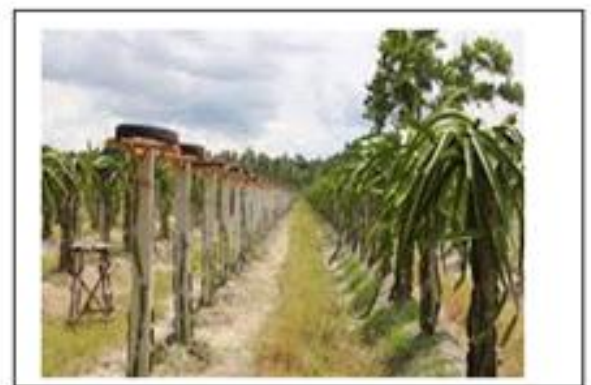

BBG - now (2014)

\section{Best Practice of Taman Kehati Desa Namang}

Besides Johan, another outstanding entrepreneur named Zaiwan, who is the head of Desa Namang, is an environmental hero who received Kalpataru recognition award from the Ministry of Environment because of his crazy idea which has turned a $52.4 \mathrm{Ha}$ land into $252,4 \mathrm{Ha}$ land, most of which is part of former mine lands that is being restored and planted with paddy plants especially brown rice, as well as produces pelawan bitter honey and the unique pelawan mushrooms. A curious issue is the relationships between indigenous Knowledge System among people in Desa Namang and the former mine lands in the structure of ecological modernization.

Reserved forest of 252,4 Ha in the area which are part of former mine lands are developed in Desa Namang. The reserved forest functions as eco-tourism area. Besides that, it also serves as source of oxygen for people in the region of Bangka Tengah. The forest consists of various species of trees including gelam, leting, pelawan, and rempodong which are also resourced by honeybees to produce honey. The pollen is used by honeybees to produce a special bitter honey which can only be found in Bangka Tengah. Here, honeybees fly around only to find nectar, pollen, propolis, and water and fly back to the beehive. This is the reason why the pelawan honey is very special compared to other types of honey. Its taste is quite distinctively bitter, but after it is swallowed, the bitter taste is gone. The pelawan honey has a bitter taste because it contains alkaloid, a type of chemical found in this type of honey which has medicinal properties, serving as anti-infectional compound to strengthen the immune system and cure a number of diseases. The development of non-timber products from forest (Pembangunan Hasil Hutan Bukan Kayu - HHBK) such as pelawan honey has been developed by a group of productive entrepreneurs in the reserved forest with help from an agency that supports village-owned enterprises named Badan Usaha Milik Desa (BUMDes).

Based on the experience of people in the local community, the months of September, October, November and December are the best season for harvesting of PELAWAN honey in the area. However, during the shift of season, or specifically at the beginning of September, the people Namang enjoys the active growth of PELAWAN mushrooms which are very tasty and very expensive (Rp.1.300.000/kg of dried PELAWAN mushrooms).

The former mine lands in this area, utilized for agricultural activities, are also developed by restoring the surface of soil and by setting in the organic matters. It took about one to two years to prepare the soil and land for early plantations. Trees planted are sengon and akasia which are planted at the outer part around the area, while the inside of the plantation area are prepared as paddy fields for planting brown rice. At the time the present study was being reported, there has been 86 hectares of paddy field ready to be planted in Desa Namang and Desa Belilik Kecamatan Namang. The development of the paddy field was sponsored by central and regional government offices. Each hectare of plantation land may produce four to five tones of rice. Further, 
more financial assistance were added by Estimated Additional Payment 2011 (Anggaran Bayaran Tambahan / ABT 2011) in September. The goal was to develop a new plantation area, which is specifically 800 hectares of paddy field in 2014..

\section{Historical Culture of Desa Namang}

In the past there was a large wooden timber named Namang/Ramin at the junction of the village, and an excellent young man lived under the large timber, He always served some water to drink to anyone who stopped there so that they can quench their thirst. He would say $\mathrm{Na}$ - Mang (NA is a word used by Bangka community which means to give, while MANG is a name to call an older person. Up until now, the village was named Desa Namang. In cultivating values, norms, ethics and vision of Namang village, the villagers then created a slogan of "PELAWAN" which is an acronym for being productive, elaborative, safe and environmentally visionary (Produktif, Elaboratif, Aman, dan berwawasan lingkungan). These values then become local wisdom among Namang communities in order to develop and improve the economic security.

This small village with a population of less than 16,625 inhabitants became famous because it has managed to preserve forests and protect the areas, to which the citizens named as PELAWAN Forest. The head of Desa Namang, Zaiwan, said that society also managed to preserve PELAWAN mushrooms and PELAWAN honey, both of which are the versions of the Ministry of Forestry and Agriculture, and are the most expensive in Indonesia. PELAWAN Forest is also often used as a research hub by various universities, such as UGM, ITB , UNSRI , UBB and many more," he said. Zaiwan admitted that early care and preservation of the PELAWAN Forest is not as easy as it is now as he had to go through various challenges including receiving mockery and ridicules. He was even dubbed as crazy by some citizens. He said, "Thank God it has now been successful. Even the whole society now is supporting the preservation of forest in this village. We are doing this preservation because we are motivated to bequeath our land to our children and grandchildren,"
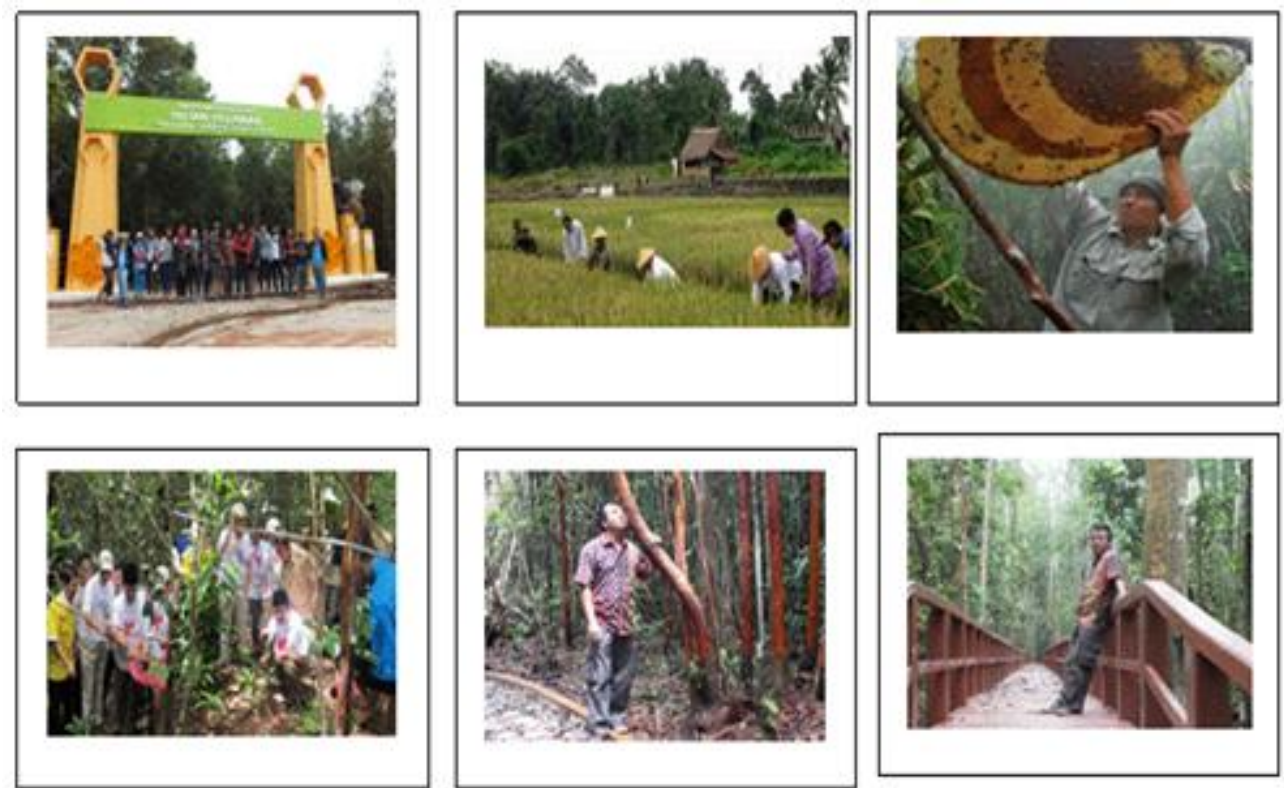

The top left to right; bottom - left to right:

:Gerbang Taman Kehati. Panen Padi Beras

Merah, Panen Madu Pahit Pelawan, Panen Jatuur Pelawan, Kayu Pelawan, Jungle Jogging Track

The Governor of Bangka Belitung Region, Dr. Eko Maulana Ali , MSc (deceased - Almarhum), was both proud and happy because the Regent of Bangka Tengah, together with the officials of Desa Namang, were able to utilize the environmental resources well. "It may change the paradigm of the people in the community who have depended their lives on tin mining, and they can turn it into planting and gardening", the Governor said in his opening speech. 


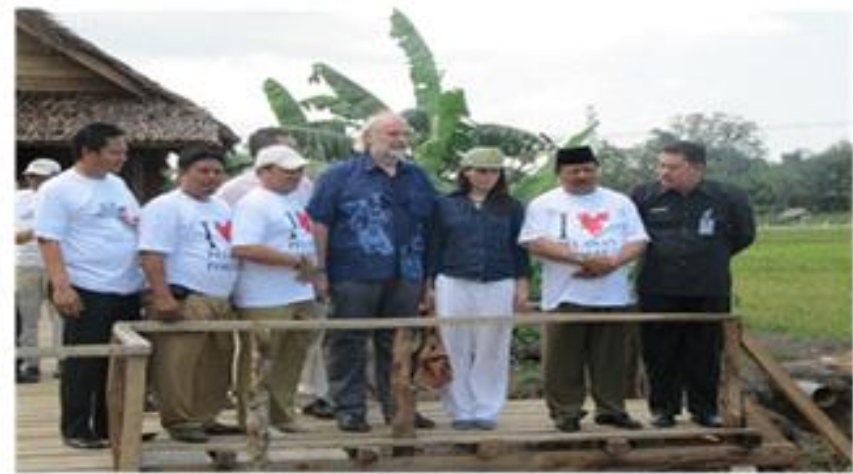

A visit by the Governor

Thanks to his efforts, Zaiwan has been awarded Wana Lestari in the Kades Peduli Alam Sekitar category, the Champion of Bangka Belitung region (Tingkat Negeri Bangka Belitung) and fifth place (5 besar) at the national level. In a social occasion held in the middle of paddy fields in Desa Namang, as a show of gratitude among farmers, zakat has been handed over directly to the residents need by the governor of Bangka Belitung. Assistants in forms of seed corn, peanuts, and rice thresher machine has also been given by the Regent of Central Bangka.

\section{Conclusion}

Based on Johan and Zaiwan's story, below are lessons learned that need to be considered about improving the environment around former mined lands:

- It has been proven that BBG and Desa Namang communities will be able to live in peace without having to completely rely on tin mine if the land is cultivated with perseverance, confidence, and value of Indigenous Knowledge Systems as well as support from stakeholders.

- It is very necessary for the stakeholders to have patience and participate holistically in order to create a paradigm shift of thinking through the best practical as transfer of knowledge to construct indigenous knowledge system in modernization of ecology.

- It is important to find out basic strategies for managing natural resources of other larger areas. Thus it is necessary to conduct more in-depth and thorough studies in coming up with the design, implementation, assessment, and reflection of practical experience. Transfer of knowledge in the area - another area with various model approaches in accordance with the potential and the characteristics of the region need assessment and designation as well as the wisdom of local communities around the mined land may be made to the green era.

\section{References}

[1]. MIPI 2013, Development with Preservation (Pembangunan Lestari), Jakarta

[2]. United Nations. 1987. Report of the World Commission on Environment and Development, General Assembly Resolution 42/187, 11 December 1987. Retrieved: 2007-11-14

[3]. Whitfield, S., Geist, H. and Ioris, A.A.R. 2011. Deliberative Assessment in Complex Socio-Ecological Systems: Recommendations for Environmental Assessment in Drylands. Environmental Monitoring and Assessment, 183(1-4), 465-483

[4]. Jalaluddin Abdul Malek, Abdul Razaq Ahmad, Mohd Mahzan Awang, Alfitri. 2014. Symbiotic Relationship Between Telecentre and Lifelong Learning For Rural Community Development: A Malaysian Experience. 13 (3), 148-155[5]

[5]. Neil AW. 2001. Social Capital and Climate Change: Tyndall Centre

[6]. Ardhana IPG 2009, Standardization of Deforestation Activities (Penyelarasan Kegiatan Pertambangan Pada Kawasan Hutan). FMIPA UNUD. Downloaded from: scholargoogle.com.

[7]. Gonick . L \& Outwater A, 2004, Cartoon on Environmental Universe (Kartun Alam Sekitar), Jakarta KPG

[8]. Maryono A, 2006, River Development Impact and River Restoration, UGM Press

[9]. Gross M \& Heinrich.H 2010, Environmental Sociology: European Perspectives and Interdisciplinary Challenges: Germany, Springer Science

[10]. Ritzer. G. \& Goodman, 2004 Theory of Modern Sociology (Teori Sosiologi Modern). : Jakarta.Prenada Media

[11]. Michael. R.R. 2010 The International Handbook of Environment Sociology: London UK, Edwar Elgar

[12]. Syarkowie, F. 2014 Agro Ecosystem for Preserving Wetlands ("Agro Ekosistem tanah Basah Lestari) Speeches on Innovation for the Power of Food and Wellness among 